\title{
DETERMINANT OF LATENT PULMONARY TUBERCULOSIS INCIDENCE AMONG HEALTH WORKERS IN COMMUNITY HEALTH CENTERS IN SURABAYA, INDONESIA
}

\author{
Susilowati Andajani \\ Department of Public Health and Preventive Medicine, Faculty of Medicine, Universitas Airlangga, Surabaya, \\ Indonesia
}

\section{ABSTRACT}

\begin{abstract}
About 2 billion people in the world are infected with latent TB, and 5-10\% of them will develop into active TB. The purpose of this study was to analyze the relationship between nutritional status, behavior, duration of work, comorbidities, and workplace ventilation with the incidence of latent pulmonary TB. This type of research is an observational cross sectional analytic, a sample of research of poly TB analysts and nurses from 13 health centers in Surabaya, a sample of 30 people. Statistical analysis with Chi Square and $t-2$ test samples were free with $\alpha=0.05$. The results of this study are: The proportion of latent TB incidence is (46.70\%) and $85.71 \%$ of them are women. None of the respondents detected DM, and none of the history had HIV, silicosis or hepatitis. All workplace ventilation is not good. There was no relationship between nutritional status, behavior, duration of work and the incidence of latent pulmonary TB. The conclusions from the study are, 1) The proportion of health center health workers affected by latent pulmonary TB infection is $46.70 \%$, 2) There is no relationship between nutritional status, length of work, and behavior of health center health workers in Surabaya with latent pulmonary TB incidence. The highest incidence of latent pulmonary TB occurred in those with a working period of five years or more, with the highest education in D3 medical analysts/akper. All workplace ventilation is not good. The highest incidence of latent pulmonary TB (42.86\%) in employees at the PRM Health Center (microscopic referral health center).
\end{abstract}

Keywords: Latent pulmonary TB; determinant; health workers

\begin{abstract}
ABSTRAK
Sekitar 2 milyar orang di dunia terinfeksi TB laten, dan 5-10\% diantaranya akan berkembang menjadi TB aktif. Tujuan dari penelitian ini adalah menganalisis adanya hubungan antara status gizi, perilaku, lama kerja, penyakit penyerta, dan ventilasi tempat kerja dengan kejadian TB Paru laten. Jenis penelitian ini observational cross sectional analytic, sampel penelitian tenaga analis dan perawat poli TB dari 13 Puskesmas di Surabaya, besar sampel 30 orang. Analisis statistik dengan Chi Square dan uji $t$ - 2 sampel bebas dengan $\alpha=0,05$. Hasil penelitian ini adalah, Proporsi kejadian TB laten sebesar (46,70\%) dan 85,71\% diantaranya wanita. Tidak satupun dari responden terdeteksi DM, dan dari anamnesis tidak ada yang menderita HIV, silikosis ataupun hepatitis. Ventilasi tempat kerja semuanya kurang baik. Tidak ada hubungan antara status gizi, perilaku, lama kerja dengan kejadian TB Paru laten. Simpulan dari penelitian adalah, 1) Proprosi tenaga kesehatan puskesmas yang terkena Infeksi TB Paru laten adalah 46,70\%, 2) Tidak terdapat hubungan antara status gizi, lama kerja, dan perilaku tenaga kesehatan Puskesmas Surabaya dengan kejadian TB Paru laten. Kejadian TB Paru laten terbanyak terjadi pada mereka dengan lama kerja lima tahun atau lebih, dengan pendidikan terbanyak D3 analis medis/akper. Ventilasi tempat kerja semuanya kurang baik. Kejadian TB Paru laten terbanyak (42,86\%) pada karyawan di Puskesmas PRM (puskesmas rujukan mikroskopis).
\end{abstract}

Keywords : TB Paru Laten; determinan; tenaga kesehatan

Correspondence: Susilowati Andajani, Wisma Permai Barat I LL/35, Surabaya. Phone: 08121622749. E-mail: susilowatiandajani@yahoo.com

pISSN:2355-8393 • eISSN: 2599-056x • doi: http://dx.doi.org/10.20473/fmi.v55i2.14348

- Fol Med Indones. 2019;55:139-146 • Received 13 Nov $2018 \bullet$ Accepted 23 May 2019

- Open access under CC-BY-NC-SA license • Available at https://e-journal.unair.ac.id/FMI/ 


\section{INTRODUCTION}

Pulmonary TB is still a global public health problem, especially in Indonesia. In the world (in 2015), around 10.4 million people suffer from pulmonary TB (Incidence rate TB 142 per 100,000 inhabitants) and 1.4 million of them died. Patients of TB + HIV amounted to 1.17 million people (Incidence rate of 11 per 100,000 inhabitants), and around 390,000 people died (WHO 2017). More than $95 \%$ of TB deaths occur in developing countries and tuberculosis is the second largest killer after HIV/AIDS for infectious diseases worldwide (WHO 2012).

Globally, 9 million people are infected with M.tb germs every year, and one third of the population or around 2 billion people are infected with M. latent TB. A person with latent $M$. tb infection has no manifestations of clinical symptoms of active tuberculosis and is not infectious, but the risk of developing into active TB infection increases and then becomes infectious. About 2 million people die each year due to active TB and ineffective treatment (CDC \& Prevention 2010).

The problem of TB in Indonesia is quite serious and is one of the biggest health problems. In 2015, Indonesia ranked second in the number of TB patients after India, with an Incidence Rate of 395 per 100,000 inhabitants and around 100,000 sufferers died. Incidence rate of sufferers (TB + HIV) of 30 per 100,000 population (78,000 sufferers) and 26,000 sufferers including death. Incidence rate of MDR/RR TB patients is 12 per 100,000 population $(32,000$ people). Overall, the mortality rate of TB patients, including (TB + HIV) is 40 per 100,000 population (WHO 2017).

The risk of transmission each year (Annual Risk of Tuberculosis Infection) in Indonesia is considered quite high and varies between 1-3\%. In areas with ARTI of $1 \%$, it means that every year among 1000 residents, 10 people will be infected. Most of the people infected will not become Tuberculosis sufferers, only about $10 \%$ of those infected will become Tuberculosis sufferers. Then it can be estimated that in areas with $1 \%$ ARTI, between 100,000 residents on average occur 100 Tuberculosis sufferers every year, of which 50 sufferers are positive smear (Minister of Health of the Republic of Indonesia, 2009).

About $75 \%$ of TB patients are the most economically productive age groups (15-50 years). It is estimated that an adult TB patient will lose an average working time of
3 to 4 months. This results in losing a household's annual income of around 20-30\%. If he dies from TB, he will lose around 15 years of income. In addition to being economically detrimental, TB also has other adverse effects on social stigma and even being ostracized by the community (Minister of Health of the Republic of Indonesia 2009)

Tuberculosis is a disease that is very closely related to the problem of poverty, where most sufferers come from various developing countries. The biggest risk factor for TB infection in Africa and Southeast Asia is HIV infection. Other factors that are closely related to socio-economic problems are low income, unemployment, house density, and low education level (Ndungu 2013).

The problem in Indonesia is that there is a tendency for an increase in pulmonary TB morbidity in health workers. Nosocomial transmission is a serious concern because the impact is not only on other sufferers but also on health workers who carry out patient care either at the health center or at the hospital (Amin 2004).

In developing countries health workers who treat $\mathrm{TB}$ sufferers carry a high risk of contracting TB. One reason is that there is no effective effort or facility to prevent transmission of TB to health workers. In countries with weak economic conditions, transmission to health workers can be reduced if the government, health authorities and health workers themselves place the highest priority on infection control. Commitment to reduce the risk of transmission of $\mathrm{M}$. nosocomial tuberculosis to health workers is very necessary to avoid them from exposure, infection, disease, disability, and death (Amin 2004).

Conventional TB diagnosis and prevention for more than a hundred years has not been able to control the TB epidemic, so the global public health threat is increasingly widespread. Until the early 20th century, the Tuberculin skin test (TST) was the only diagnostic method for detecting latent TB. The disadvantages of TST are that it takes two visits to read results in 48-72 hours, problems in interpreting the results due to cross reactivity with mycobacterium other than tuberculosis (MOTT), booster effects, and false negative results if there are immunosuppressed conditions, and variability in the application and reading the results. Weaknesses in the TST led to the development of tests to measure the response to tuberculosis antigens. 
Currently a new method has been found for the diagnosis of latent $M$. tuberculosis/LTBI (Latent tuberculosis infection), namely by IGRA examination. The high specificity of IGRA/QuantiFERON-TB Gold (> 99\%) in low-risk individuals can eliminate false positives produced by TST. IGRA sensitivity is $>92 \%$ in individuals with TB infection, depending on the location and spread of TB. The results of IGRA examination are not affected by pregnancy. Screening with IGRA examination in individuals exposed to tuberculosis germs is expected to improve $\mathrm{TB}$ case control.

In Indonesia, there have been no official reports on the prevalence/proportion of latent TB in health workers. Based on the above description, a study will be conducted on "Determining the incidence of latent pulmonary TB in health workers at the Surabaya health centers".

\section{MATERIALS AND METHODS}

The design of this study was an observational analytic cross sectional study with a sample of laboratory personnel examining suspected pulmonary TB sputum and nurses at pulmonary TB Poly from 13 health centers in Surabaya. The exclusion criteria in this study were laboratory workers and poly TB nurses from health centers in Surabaya who moderate and/or ever suffering from pulmonary TB. The sample size in this study was 30 people, with a non random sampling sampling technique. The independent variables in this study were nutritional status, behavior, length of work, health worker co-morbidities, and workplace ventilation area, while the dependent variable was the incidence of latent pulmonary $\mathrm{TB}$ in the $\mathrm{TB}$ nurses of $\mathrm{TB}$ and laboratory personnel from 13 health centers in Surabaya.

The instruments in this study were structured questionnaires, observation sheets, random blood sugar check kits, IGRA kits, tools for measuring the area of workplace ventilation, tools for measuring TB and BB. The research site was in 13 health centers from East, North, South, West, and Central Surabaya, with a research period of 6 months from June 1 to November 30, 2014. The data collected was primary data and secondary data. Primary data is data collected by researchers who included $\mathrm{TB}$ and $\mathrm{BB}$ to determine nutritional status (BMI), behavior, and length of work of health workers, extensive workplace ventilation, random blood sugar checks and IGRA tests. Random blood sugar checks with on call plus, and declared diabetes mellitus if the value of blood sugar levels are the same or above $200 \mathrm{mg} / \mathrm{dl}$. IGRA test with QuantiFERON-TB Gold which is done by Prodia laboratory with blood collection of $3 \mathrm{CC}$ for health workers. The results of the positive IGRA test showed that respondents were positive for latent pulmonary TB. Secondary data was taken from the reporting of pulmonary TB patients reporting from 13 health centers in Surabaya.

Data from blood tests, interviews, measurements and observations were then carried out by editing, coding, data entry, and cleaning. Then the data is processed with the following stages: 1) Data on respondent characteristics are presented descriptively in the form of frequency distribution using tables or graphs. 2) Data on independent and dependent variables are nominal, and statistical analysis is carried out by Chi Square test to see the relationship of risk factors to the incidence of pulmonary TB

\section{RESULTS}

The health centers used for this study were 13 health centers consisting of 7 Satellite Health Centers (PS), 3 Independent Health Centers (PPM), and 3 Microscopic Referral Health Centers (PRMs). Thirteen health centers have quite a lot of pulmonary TB patients. The number of respondents is 30 people, and most of $46.70 \%$ come from Satellite Health Centers (13 respondents). Sixteen respondents $(53.30 \%)$ worked in a laboratory that examined suspect sputum with pulmonary TB (Table 1).

The sex of the most respondents is women, namely 23 people $(76.70 \%)$, while men have 7 people $(23.40 \%)$. Based on the education level 23 respondents $(76.70 \%)$ were educated D3 Analysts/Actors, followed by S1 4 respondents $(13.30 \%)$, and the highest number of workplaces $(53.30 \%)$ in the laboratory (Table 1$)$. All the results of random blood sugar examinations were not suspected of diabetes mellitus, whereas the results of IGRA examination by Prodia, there were 14 positive IGRA people (46.70\%), which can be seen in Table 1 .

The youngest respondent aged 25 years and the oldest was 59 years old, with an average age of $36.63+8.861$ which was a productive age. The majority of respondents $(56.66 \%)$ have more nutritional status, and only 1 person is underweight. Nine $(64.29 \%)$ of the 14 people diagnosed with latent pulmonary TB were over nutrition. 
Table 1. Characteristics of Respondents

\begin{tabular}{llcc}
\hline & & $\mathrm{n}$ & $\%$ \\
\hline Sex & Male & 7 & 23.3 \\
Education & Female & 23 & 76.7 \\
& High School & 3 & 10.0 \\
\multirow{3}{*}{ Types of Health Center } & Diploma in Analyst/Nursing & 23 & 76.7 \\
& Bachelor degree & 4 & 13.3 \\
& Satellite HC & 14 & 46.7 \\
\multirow{3}{*}{ Workplace } & Microscopic Referral HC & 8 & 26.7 \\
& Independent HC & 8 & 26.7 \\
& Laboratory & 16 & 53.3 \\
& Clinic & 14 & 46.7 \\
& Positive & 14 & 46.7 \\
\hline
\end{tabular}

Table 2. Average age, length of work, family income, levels of RBS and BMI of respondents

\begin{tabular}{lcc}
\hline & $\mathrm{n}$ & Mean $\pm \mathrm{SD}$ \\
\hline Age (years) & 30 & $36.63 \pm 8.861$ \\
Length of work (years) & 30 & $9.27 \pm 6.040$ \\
Income & 30 & $5003.00 \pm 2006.634$ \\
RBS level & 30 & $102.23 \pm 17.182$ \\
BMI & 30 & $26.063 \pm 5.056$ \\
\hline
\end{tabular}

Table 3. Distribution of latent pulmonary TB incidence based on the nutritional status of respondents

\begin{tabular}{lccc}
\hline \multirow{2}{*}{ Nutritional status } & Positive & IGRA & Total \\
\hline Under & $0(0.0 \%)$ & Negative & $1(3.33 \%)$ \\
Normal & $5(35.71 \%)$ & $7(6.25 \%)$ & $12(40.0 \%)$ \\
Over & $9(64.29 \%)$ & $8(47.1 \%)$ & $17(56.67 \%)$ \\
Total & $14(100 \%)$ & $16(100 \%)$ & $30(100.0 \%)$ \\
\hline
\end{tabular}

Table 4. Relationship between nutritional status and the incidence of latent pulmonary TB

\begin{tabular}{|c|c|c|c|c|}
\hline \multirow{2}{*}{ Nutritional Status } & \multicolumn{2}{|c|}{ IGRA } & \multirow{2}{*}{ Total } & \multirow{2}{*}{$\mathrm{p}$} \\
\hline & Positive & Negative & & \\
\hline Under - Normal & $5(38.5 \%)$ & $8(61.5 \%)$ & $13(100.0 \%)$ & \multirow{3}{*}{0.676} \\
\hline Over & $9(52.9 \%)$ & $8(47.1 \%)$ & $17(100.0 \%)$ & \\
\hline Total & $14(46.7 \%)$ & $16(53.3 \%)$ & $30(100.0 \%)$ & \\
\hline
\end{tabular}

Table 3 shows that there is 1 cell which is worth less than 5 (under nutrition status), so it must be combined with normal nutritional status so that statistics can be analyzed by Chi Square test, which can be seen in Table 4. Based on the Chi Square statistical test $(\alpha=0.05)$, there was no relationship $(\mathrm{p}=0.676)$ between nutritional status and the incidence of latent pulmonary TB (positive IGRA). The results of the statistical test with Chi Square $(\alpha=0.05)$, there is no relationship $\mathrm{p}=0.676$ ) between the behavior of respondents with the incidence of latent pulmonary TB. From 30 respondents no one had DM. Based on Table 6 above, most (11 people) patients with latent pulmonary TB have random blood sugar levels of less than 110. The results of the statistical test with Chi Square $(\alpha=0.05)$ there is no relationship $(\mathrm{p}=0.689)$ between blood sugar levels $>110$ $\mathrm{mg}$ with the incidence of latent pulmonary TB. 
Table 5. Relationship between the behavior of respondents with the incidence of pulmonary TB

\begin{tabular}{lcccc}
\hline \multicolumn{1}{c}{ Behavior } & Positive & IGRA & Total & p \\
\hline Good & $9(52.9 \%)$ & $8(47.1 \%)$ & $17(100.0 \%)$ & \multirow{2}{*}{0.676} \\
Poor & $5(38.5 \%)$ & $8(61.5 \%)$ & $13(100.0 \%)$ & \\
Total & $14(46.7 \%)$ & $16(53.3 \%)$ & $30(100.0 \%)$ & \\
\hline
\end{tabular}

Table 6. Relationship between RBS levels and the incidence of latent pulmonary TB

\begin{tabular}{|c|c|c|c|c|}
\hline \multirow{2}{*}{ RBS level } & \multicolumn{2}{|c|}{ IGRA } & \multirow{2}{*}{ Total } & \multirow[b]{2}{*}{$\mathrm{p}$} \\
\hline & Positive & Negative & & \\
\hline$<110$ & $11(50.0 \%)$ & $11(50.0 \%)$ & $22(100.0 \%)$ & \\
\hline$\geq 110$ & $3(37.5 \%)$ & $5(62.5 \%)$ & $8(100.0 \%)$ & 0.689 \\
\hline Total & $14(46.7 \%)$ & $16(53.3 \%)$ & $30(100.0 \%)$ & \\
\hline
\end{tabular}

Table 7. Distribution of latent pulmonary TB incidence by type of health center

\begin{tabular}{lccc}
\hline $\begin{array}{c}\text { Type of Health } \\
\text { Center }\end{array}$ & Positive & IGRA & Total \\
\hline Satellite & $4(28.57 \%)$ & $10(62.50 \%)$ & $14(46.67 \%)$ \\
Microscopic & $6(42.86 \%)$ & $2(12.50 \%)$ & $8(26.67 \%)$ \\
Independent & $4(28.57 \%)$ & $4(25.00 \%)$ & $8(26.67 \%)$ \\
Total & $14(100.0 \%)$ & $16(100.0 \%)$ & $30(100.0 \%)$ \\
\hline
\end{tabular}

Table 8. Relationship between types of health centers with the incidence of latent pulmonary TB

\begin{tabular}{ccccc}
\hline \multicolumn{1}{c}{ Type of Health } & IGRA & \multirow{2}{*}{ Total } & P \\
Centers & Positive & Negative & $22(100.0 \%)$ & \\
\hline Satellite/Micros & $8(36.4 \%)$ & $14(63.6 \%)$ & $8(100.0 \%)$ & 0.101 \\
Independent & $6(75.0 \%)$ & $2(25.0 \%)$ & $30(100.0 \%)$ & \\
Total & $14(46.7 \%)$ & $16(53.3 \%)$ & \\
\hline
\end{tabular}

Table 10. Distribution of latent pulmonary TB incidence according to length of work

\begin{tabular}{lccc}
\hline \multirow{2}{*}{ Length of Work } & Positive & IGRA & Total \\
\hline$\leq 5$ years & $3(37.5 \%)$ & $5(62.5 \%)$ & $8(100.0 \%)$ \\
$6-10$ years & $6(42.9 \%)$ & $8(57.1 \%)$ & $14(100.0 \%)$ \\
$>10$ years & $5(62.5 \%)$ & $3(37.5 \%)$ & $8(100.0 \%)$ \\
\multicolumn{1}{c}{ Total } & $14(46.7 \%)$ & $16(53.3 \%)$ & $30(100.0 \%)$ \\
\hline
\end{tabular}

Table 7 shows that the majority $(42.86 \%)$ of respondents who suffer from latent pulmonary TB work in a microscopic referral health center (PRM). The results of the Chi Square statistic test $(\alpha=0.05)$ there was no relationship $(\mathrm{p}=0.101)$ between the types of health centers with the incidence of Latent Pulmonary TB. Based on Table 10, the majority of respondents (46.67\%) had worked between 6-10 years and $42.90 \%$ of them were affected by Latent Pulmonary TB. The results of the Chi Square statistical test $(\alpha=0.05)$ there were no differences $(p=0.417)$ between the length of work of more than 10 years or less than 10 years with the incidence of Latent Pulmonary TB. The results of the Chi Square statistical test $(\alpha=0.05)$ there was no relationship $(\mathrm{p}=0.478)$ between the workplace and the incidence of Latent Pulmonary TB. Based on table 13. the above $(64.28 \%)$ of Latent Pulmonary TB sufferers were educated D3 Analysts/Akper. Based on the mean values of BMI, duration of work, and levels of RBS with t-test 2 free samples, there was no difference $(\mathrm{p}=0.450, \mathrm{p}=0.397, \mathrm{p}=0.808)$ between patients with LTBI and non-LTBI. 
Table 11. Differences in the incidence of latent pulmonary TB based on work time

\begin{tabular}{lcccc}
\hline \multirow{2}{*}{ Length of Work } & Positive & IGRA & \multirow{2}{*}{ Total } & \multirow{2}{*}{ Negative } \\
\hline$\leq 10$ years & $9(40.9 \%)$ & $13(59.1 \%)$ & $22(100.0 \%)$ & \\
$>10$ years & $5(62.5 \%)$ & $3(37.5 \%)$ & $8(100.0 \%)$ & 0.417 \\
$\quad$ Total & $14(46.7 \%)$ & $16(53.3 \%)$ & $30(100.0 \%)$ & \\
\hline
\end{tabular}

Table 12. Relationships between workplaces and the incidence of latent pulmonary TB

\begin{tabular}{|c|c|c|c|c|}
\hline \multirow{2}{*}{ Workplace } & \multicolumn{2}{|c|}{ IGRA } & \multirow{2}{*}{ Total } & \multirow{2}{*}{$\mathrm{P}$} \\
\hline & Positive & Negative & & \\
\hline Laboratory & $6(37.5 \%)$ & $10(62.5 \%)$ & $16(100.0 \%)$ & \\
\hline Clinic & $8(57.1 \%)$ & $6(42.9 \%)$ & $14(100.0 \%)$ & 0.478 \\
\hline Total & $14(46.7 \%)$ & $16(53.3 \%)$ & $30(100.0 \%)$ & \\
\hline
\end{tabular}

Table 13. Distribution of latent pulmonary TB incidence according to education level

\begin{tabular}{lccc}
\hline \multicolumn{1}{c}{ Education Level } & Positive & IGRA & Negative \\
\hline High School & $2(66.7 \%)$ & $1(33.3 \%)$ & $3(100.0 \%)$ \\
Diploma in & $9(39.1 \%)$ & $14(60.9 \%)$ & $23(100.0 \%)$ \\
Analyst/Nursing & $3(75.0 \%)$ & $1(25.0 \%)$ & $4(100.0 \%)$ \\
Bachelor degree & $14(46.7 \%)$ & $16(53.3 \%)$ & $30(100.0 \%)$ \\
\hline \multicolumn{1}{c}{ Total } & & &
\end{tabular}

Table 14. Distribution of latent pulmonary TB incidence (LTBI) according to the mean of BMI, length of work and RBS levels

\begin{tabular}{lcccc}
\hline & IGRA & $\mathrm{n}$ & Mean \pm SD & $\mathrm{p}$ \\
\hline BMI & Positive & 14 & $26.825 \pm 4.875$ & 0.450 \\
& Negative & 16 & $25.396 \pm 5.273$ & \\
Length of Work & Positive & 14 & $10.29 \pm 6.81$ & 0.397 \\
(years) & & & & \\
& Negative & 16 & $103.07 \pm 16.786$ & 0.808 \\
RBS level & Positive & 14 & $101.50 \pm 18.037$ & \\
& Negative & 16 & & \\
\hline
\end{tabular}

\section{DISCUSSION}

About $90 \%$ of people infected with M. tuberculosis have asymptomatic latent TB infections (LTBI/Latent TB infections) (Skolnik, 2011). Opportunity for LTB1 to develop into active TB is around $5-10 \%$. People who make long-term contact, often frequently, or always close to active TB patients, are at high risk of becoming infected, with estimates of infection rates of around 22\% (Hasnain et al., 2011).
Factors that influence the occurrence of pulmonary TB infection according to the CDC (2011) include the number of infectious points sprayed by patients with active TB (droplet) during coughing, sneezing, and speech, the effectiveness of ventilation of the living environment, duration of exposure, level of virulence strain $\mathrm{M}$ tuberculosis, and the level of immunity of the person concerned.

The results of this study were higher than Hasnain's estimate of $22 \%$, ie $14(46.70 \%)$ of 30 poly 
TB/laboratory health workers in Surabaya health centers were infected with $M$. tuberculosis. The main transmission from active TB sufferers to health workers is through droplets with long exposure periods, because so far sufferers and health workers do not wear masks and recently they wear masks. This can be seen from the average length of work of patients with LTBI is $10.29 \pm$ 6.81 years at intervals of 3-30 years.

The results of this study were all inadequate ventilation of respondents' workplaces. Fourteen health centers in the study did not have Poly which was specifically for TB patients, but became one with general poly or ER, or poly leprosy. Poly TB nurses also serve as general poly nurses or ER. Poli TB is one with the general poly, services for TB patients are carried out at 07.00 a.m. at 08.00 by opening all windows and doors. After completing TB service, the windows and doors are closed, the air conditioner is turned on, even though there are still many TB germs from TB patients treated the previous morning. There are special services for TB sufferers every Saturday, to reduce the possibility of passing a common patient. At present all people with pulmonary $\mathrm{TB}$ are required to wear masks when they go to the health center and at home.

Most laboratory rooms in Surabaya Health Center are air-conditioned because in the room there are equipment for clinical chemistry examinations, and others that must be maintained. At the time of making phlegm preparations, there are laboratory personnel who make it outdoors and some in the laboratory by turning off the air conditioner, opening the doors and windows. After the work is finished the doors and windows are closed, the air conditioner is turned on even though the possibility in the laboratory air still has TB germs.

Some of the factors that are why people are more susceptible to TB infection include HIV, diabetes mellitus, smoking, alcoholism, being treated with immunosupressants such as long-term corticosteroids, and others. At the global level, the most important risk factor for TB infection is HIV; $13 \%$ of all TB cases were also infected by the HIV virus (WHO 2011). This problem is common in sub-Saharan Africa, where HIV rates are high. The risk of TB in people with HIV to develop into active disease increases by about $10 \%$ every year. If not given effective treatment, then the active TB mortality rate can reach more than $66 \%$. In patients with diabetes mellitus (DM) have a risk 3 times greater for TB exposure than those without DM.
In this study, laboratory tests were not conducted for detection of the HIV virus because of limited funding but from history not infected by the HIV virus. None of the randomized blood sugar examinations were suspected of diabetes mellitus (DM) with a mean random blood sugar level in LTBI of $103.07+16,786$, and the results of the statistical tests showed no significant differences.

Tuberculosis is closely related to excessive population density and malnutrition. This link makes TB one of the main diseases of poverty (Zumla et al., 2011). People who have a high risk of being infected with TB related to this include intravenous drug users (IDUs), residents and employees gathering places for vulnerable people (for example, prisons and homeless shelters), poor people who do not have access to adequate health care, high-risk ethnic minorities, and health workers who serve these people (WHO 2007).

The results of this study, 17 people $(56.67 \%)$ had more nutrition and 9 people $(52.94 \%)$ of whom were exposed to LTBI, while one person with malnutrition was not affected by the LTBI. The average BMI on the LTBI is $26,825 \pm 4,875$. Statistical analysis did not find a relationship between nutritional status and the incidence of LTBI. This is possible because the measurement of nutritional status is currently, while the process of occurring the disease has been long. The average body mass index of all respondents was $26,063+5,056$.

Associated with respondents' income/family average of $5,003,000+2,006,634$ with an interval of 2,200,000$9,000,000$ rupiah. Those who earn less than 2.5 million (4 people) are unmarried, and there are 4 respondents with LTBI who earn the same or under 3 million rupiah. The results of the statistical analysis have no relationship between family income and the incidence of the LTBI. This might be because the sample size is not large or the actual family income is greater.

Chronic lung disease is another important risk factor. Silicosis increases risk up to 30 times greater. People who smoke have a risk twice as much as TB than nonsmokers, while alcoholism has a threefold risk (Restrepo 2007). Certain drugs, such as corticosteroids and infliximab (anti-TNF monoclonal antibodies) are also important risk factors, especially in developing countries.

The results of this study were not obtained by respondents who were silicosis or who were taking 
immunosuppressive drugs, while the two men who were affected by LTBI were smokers from a young age, so they were susceptible to TB.

The behavior of laboratory officers in the speed of sputum examinations is generally good ( $<4$ days), except in the PRM Health Center the results of the examination are up to 14 days and this also causes delays in treatment. The results of the statistical analysis showed that there was no relationship between the behavior of officers and the occurrence of the LTBI.

\section{CONCLUSION}

The proportion of health center staff affected by latent TB infection is $46.70 \%$. There was no correlation between nutritional status, length of work, and behavior of health center health workers in Surabaya with the incidence of latent pulmonary TB. The highest incidence of latent pulmonary TB occurred in those with a working period of five years or more, with the highest education in D3 medical analysts/akper. All respondents did not have DM, HIV, or silicosis. All workplace ventilation is not good. The highest incidence of latent pulmonary TB (42.86\%) in PRM health centers.

\section{ACKNOWLEDGMENT}

I express my gratitude to, the Rector of Universitas Airlangga who has funded this research, the Head of the Surabaya City Health Office who has allowed research samples in his work area, Dr. Florentina Sustini, Dr., MS and Atika, SSi, M.Kes who have assisted in data collection and analysis, Nurses and laboratory staff who have been willing to participate in this research.

\section{REFERENCES}

Aditama TY (2003). Rokok dan tuberkulosis paru. Jakarta, Jurnal Kedokteran dan Farmasi Medika No.5, tahun ke-XXIX
Chan J, TianY, Tanaka KE,Tsang MS, YU K, Salgame P, Caroll D, Kress Y, Teitelbaum R, Bloom BR (1996). Effect of protein calorie malnutrition on tuberculosis in mice. USA, Proc Natl Acad Sci 93, 14857-61

Departemen Kesehatan RI (2002). Pedoman Penanggulangan Tuberkulosis. Jakarta, Departemem Kesehatan RI

Departemen Kesehatan RI (2008). Pedoman Nasional Penanggulangan Tuberkulosis. 2nd ed. Jakarta, Departemen Kesehatan RI

Gordis L (2008). Section II: Using epidemiology to identify the causeof disease. In: Epidemiology. 4th ed. Philadelphia, Saunders Elsevier Herchline 2014 Tuberculosis. Available from emedicine.medscape. com/article/230802-overview

Karim MR, Rahman MA, Mamun SAA, Alam MA,Akhter S (2012). What cannot be measured can not be done; Risk factor for childhood tuberculosis: A case control study. Bangladesh Med Resp Counc Bull $38,27-32$

Kementerian Kesehatan Republik Indonesia (2016). Peraturan Menteri Kesehatan Republik Indonesia Nomor 67 Tahun 2016 tentang Penanggulangan Tuberkulosis. Jakarta, Kementerian Kesehatan Republik Indonesia

Lemos MP, Rhee KY, McKinney JD (2011). Expression of the leptin receptor outside of different sampling models. In: Applied logistic regression. 2nd Ed. New York, John Wiley \& Sons, p 203-10

Lestari P, Sustini F, Endaryanto A, Asih R (2011). Home humidity increased risk of tuberculosis in children living with adult active tuberculosis cases. Universa Medicina 30, 138-45

Menteri Kesehatan Republik Indonesia (2009). Pedoman Penanggulangan Tuberkulosis. Jakarta, Keputusan Menteri Kesehatan RI

Ndungu P, Ndungu G, Revathi S, Kariuki, Ng'ang'a Z (2013). Risk factors in the transmission of tuberculosis in Nairobi: A descriptive epidemiological study. Available from: http://dx.doi.org/10.4236/aim.2013. 32025

WHO (2017). Tuberculosis 